\title{
Growth and yield performance of lettuce (Lactuca sativa L.) under protected and conventional cultivation
}

\author{
Nelda R. Gonzaga", Sarah Lyn A. Pepito', Renan P. Octavio', Apolinario B. \\ Gonzaga Jr' and Gordon Rogers ${ }^{2}$
}

\begin{abstract}
Protected cultivation is not widely used in the Philippines, despite its known benefits, because of lack of uptake by farmers who have not seen the benefits demonstrated in their region. Furthermore, lettuce can be a difficult crop to grow in the Philippines, where heavy rains can damage the delicate leafy crop. This study aimed to evaluate the performance of different lettuce varieties when grown under protected structures that prevent rain entry. The study was laid out in split-plot arranged in Randomized Complete Block Design (RCBD) with cultivation system (protected cropping \& open field) as the main plot while the lettuce variety (leafytype \& head-type) as the sub-plot, replicated three times. The protective structure enhanced crown size, increased yield and produced healthier plants with reduced incidence of disease. Leafy-type obtained the largest crown size and head-type was less affected by disease in the first cropping. The study suggested that protective structures can be an asset in the enhancement and sustainability of lettuce production in preventing further damage on crops due to excessive rainfall and wind but would not be profitable when use during warmer months.
\end{abstract}

Keywords: crown size, head-type lettuce, leafy-type lettuce, lessened diseases, protective cropping

\section{INTRODUCTION}

Lettuce production in the Philippines doubled in a span of 10 years. In 2001, the area was only 211 ha but in 2010 , it grew as much as 466 ha (Briones \& Galang 2012). Lettuce has a high market potential due to increasing demand for salad vegetables. In fact, it is one of the few branded vegetables available in supermarkets, and some of these brands are owned by large producers (Fang-asan et al 2009).

\footnotetext{
' College of Agriculture University of Science and Technology of Southern Philippines - Claveria MOSCAT Compound, Poblacion, Claveria 9004, Misamis Oriental, Philippines

${ }^{2}$ Applied Horticultural Research, Eveleigh, NSW Australia
}

\footnotetext{
* Corresponding Author. Address: University of Science and Technology of Southern Philippines Claveria, MOSCAT Compound, Poblacion, Claveria 9004, Misamis Oriental, Philippines; Email: npr.gonzaga@gmail.com DOI: $10.32945 /$ atr39sb11.2017
} 
Iceberg (head-type) lettuces are characterized by their relatively large, spherical, while romaine (leafy) lettuce has large, cylindrical, and semi-firm heads. Both heads are composed of leaves that are spirally arranged but head-type form a sphere of broadly shape (obovate) leaves, where the length and width of each leaf is nearly identical while leafy heads loosely clasping upon one another forming a roll of elongated, spatula-shaped (spatulate) leaves, where the length is normally $50 \%$ longer than the width. Leafy generally had semi-open head formation while headtype have a closed head formation (Waycott 2004).

The total world area of glasshouses is estimated to be over $41,000 \mathrm{ha}$, mostly found in Northwest Europe. PVC film for greenhouses is still dominant in Asia, especially in Japan $(35,200 \mathrm{ha})$, and low-density polyethylene is also used in Italy (500 ha) and Greece (Jensen 2001). The types of protective structures used by growers in Asia ranges from simple structures such as rain shelters, shade houses, row covers and plastic tunnels, to permanent structures covered in plastic or glass with computerized environmental controls which can be linked to soil-based or soilless production systems (Gonzaga et al 2013). Protected cultivation can produce horticultural crops that would otherwise be unavailable for much of the year if it was field-grown. This can lead to enhancement of the communities' economic wellbeing (Jensen 2001).

Everaarts and de Putter (2008) confirmed improved radiation level inside the bamboo constructed plastic houses led to increased yields and profits, improved plant arrangement, stem density and number of stems per plant yielded more than $19 \mathrm{~kg}$ in sweet pepper. Low-cost shelters increased lettuce production (Gerona et al 2014).

The use of high tunnels protects crops from rain and severe weather events and allows continuous production during the rainy season (Lamont 2009). Protective structures guard crops from rain, wind and extreme environmental conditions (Rogers et al 2013, Gerona et al 2015).

Wittwer and Castilla (1995) reported that many soil-borne diseases and pests have been controlled or eliminated through the use of protected cultivation.

In the Philippines, particularly in Claveria, protected cultivation is not widely used. The majority of the local growers have no or little knowledge about this new type of cultivation. Farmers usually think protected cropping requires a costly structure that would be unprofitable, leaving this modern cropping system unpracticed. The study was conducted to evaluate varietal performance of lettuce when grown under conventional and protected cropping. Specifically, the study aimed to (1) evaluate the growth performance and yield of leafy-type and head-type lettuce, (2) assess the incidence of disease among various lettuce varieties grown under different types of cultivation.

\section{MATERIALS AND METHODS}

\section{Experimental Site}

The experiment was conducted at the Agriculture Experiment Station of University of Science and Technology of Philippines - Claveria Campus, Claveria, Misamis Oriental. This has an elevation of 650 meters above sea level (masl). The soils in upland areas of Claveria are derived from pyroclastic materials, deep, well- 
Growth and yield performance of lettuce

drained and represent most of acid uplands in Southeast Asia (Mercado et al 2010).

\section{Experimental Design and Treatments}

Two trials were conducted. The study on protected cultivation method was done from July to October 2016 while for the open field cultivation system, the first cropping was done on September to October 2016, and the second cropping was on February to April 2017.

The study was laid out in a split-plot arranged in Randomized Complete Block Design (RCBD) with the following treatment combinations: Main plot - Cultivation System $\left(A_{1}=\right.$ Protected Cropping; $A_{2}=$ Open Field $)$ and sub-plot - lettuce variety $\left(B_{1}=\right.$ Leafy-type, $B 2=$ Head-type). Each treatment combination was replicated three times.

\section{Cultural Management Practices}

The protected structure used in the study were made up of heat resistant plastic film and rigid pipes measures $6 \mathrm{~m}$ wide and $47 \mathrm{~m}$ long.

The land was cultivated and harrowed twice thoroughly using draft animal. Raised beds measures $1 \mathrm{mx} 6 \mathrm{~m}$ with 3 rows per plot having 8 plants each row. There was $1 \mathrm{~m}$ distance between plots and $0.5 \mathrm{~m}$ between treatments.

A sterilized soil mixture of garden soil, vermi cast, lime and sand with a ratio of 4:5:1/2:1 on a seedling tray served as a planting medium for the lettuce seedlings. Seedlings were raised in an enclosed nursery to keep safe from infestations prior to transplanting. Seedlings were transplanted at about four to five weeks after sowing. Each plot had a planting distance of $0.3 \mathrm{~m} \times 0.3 \mathrm{~m}$. The study used the Romaine $\left(1^{\text {st }}\right.$ cropping) and Xanadu ( $2^{\text {nd }}$ cropping $)$ for leafy-type variety and Iceberg for the headtype variety for both cropping periods.

Basal application of $10 \mathrm{~g}$ Vermicast was applied prior to transplanting. Side dress application were applied with $0.27 \mathrm{~g}$ urea (46-0-0), $1.85 \mathrm{~g}$ Solophos $(0-18-0)$ and $0.89 \mathrm{~g}$ potash (0-0-60), scheduled at 7, 14, and 21 DAT.

A drip irrigation system was installed immediately after transplanting. Drip lines were aligned parallel in every row. Irrigation was usually applied two hours every day from 7:00am to 9:00am every morning, except when rain occurred and it was switched off.

Lettuces were harvested when the head was full and compact at about 30 days after transplanting.

\section{Data Collection and Analysis}

Parameters such as plant stand (\%), crown size (polar \& equatorial length), yield per plant (marketable \& non-marketable), yield per hectare and disease incidence assessment were gathered.

Data obtained were subjected to analysis of variance (ANOVA) using ASSISTAT (version 7.0 beta). The Tukey test was used to determine the significant differences among treatments means at $p<0.05$ level of significance. 
Gonzaga et al

\section{RESULTS AND DISCUSSIONS}

\section{Crown Size}

The protected cropping system increased height of lettuce heads for two successive cropping periods (Table 1). The same notable effect was reported on the head width during the second cropping. Leafy-type produced the largest crown size, both of polar and equatorial, compared to the head-type variety.

Table 1. Effect of different cultivation system on the crown size between varieties of lettuce

\begin{tabular}{lcccc}
\hline \multirow{2}{*}{ Treatments } & \multicolumn{5}{c}{ Crown Size $(\mathrm{cm})$} \\
\cline { 2 - 5 } & \multicolumn{3}{c}{ Polar } & \multicolumn{3}{c}{ Equatorial } \\
\cline { 2 - 5 } & FC & SC & FC & SC \\
\hline Cultivation System (A) & & & 19.00 & $15.50 \mathrm{a}$ \\
$\quad$ Protective Cropping & $23.67 \mathrm{a}$ & $21.83 \mathrm{a}$ & 17.68 & $13.34 \mathrm{~b}$ \\
$\quad$ Open Field & $19.73 \mathrm{~b}$ & $14.39 \mathrm{~b}$ & & \\
\hline Variety (B) & & & $24.85 \mathrm{a}$ & $18.13 \mathrm{a}$ \\
$\quad$ Leafy-Type & $32.55 \mathrm{a}$ & $26.11 \mathrm{a}$ & $11.83 \mathrm{~b}$ & $10.71 \mathrm{~b}$ \\
Head-Type & $10.85 \mathrm{~b}$ & $10.11 \mathrm{~b}$ & & \\
\hline
\end{tabular}

FC - First Cropping, SC - Second Cropping

Means in a column having the same letter are not significantly different at $5 \%$ level.

\section{Yield Parameters}

Lettuce grown under protected structures produced the heaviest marketable yield for both cropping seasons, which could be attributed to larger crown size compared with those cultivated in the open field (Table 2). Subsequently resulted into $6-47 \%$ increase in yield per hectare on both growing period confirms previous findings of Gerona et al (2014). Protected structure served as protection of crop from rain and some extent wind (Rogers et al 2013) and extreme temperatures (Gerona et al 2015) which coud explained the increase in production although relatively higher amount of rainfall occurred (Table 4). Another contributing factor is reduced disease infestation as reported that soil-borne diseases and pests (Wittwer \& Castill 1995) and foliage diseases (Rogers et al 2013) could be controlled or eliminated through protected cultivation. However, protected shelters produced also higher yield for non-marketable compared with those grown in the open field mainly because of temperature. Protective cultivation noted higher temperature which might cause tipburn (Sherf \& Macnab 1986 referred by Mashego 2007) affecting the marketability of yield and quality of lettuce. There was an increase of yield under protected structure during the first cropping but was of minor value suggests that usage of shelters would not be profitable during warmer months.

Lettuce grown at the open field during the second cropping revealing a notable decrease in yield could be correlated with having the highest disease incidence as disease limits development and growth of plants. This result might also be attributed to receiving lesser amount of rainfall compared with the other cropping and faster wind speed (Table 4). 
Growth and yield performance of lettuce

Table 2. Yield performance of lettuce in response to varying system of cultivation among varieties

\begin{tabular}{|c|c|c|c|c|c|c|}
\hline \multirow{3}{*}{ Treatments } & \multicolumn{4}{|c|}{ Yield Per Plant (grams) } & \multicolumn{2}{|c|}{$\begin{array}{c}\text { Marketable Yield } \\
\qquad\left(\mathrm{t} \mathrm{ha}^{-1}\right)\end{array}$} \\
\hline & \multicolumn{2}{|c|}{ Marketable } & \multicolumn{2}{|c|}{ Non - Marketable } & \multirow[t]{2}{*}{$\mathrm{FC}$} & \multirow[t]{2}{*}{ SC } \\
\hline & FC & SC & $\mathrm{FC}$ & SC & & \\
\hline \multicolumn{7}{|l|}{ Cultivation System (A) } \\
\hline Protective Cropping & $234.16 a$ & $243.66 a$ & $204.83 a$ & 234.16 & $23.41 a$ & $24.36 a$ \\
\hline Open Field & $219.29 b$ & $128.10 \mathrm{~b}$ & $153.21 \mathrm{~b}$ & 121.58 & $21.92 b$ & $12.81 \mathrm{~b}$ \\
\hline \multicolumn{7}{|l|}{ Variety (B) } \\
\hline Leafy-Type & $179.80 \mathrm{~b}$ & $209.76 a$ & $99.25 \mathrm{~b}$ & 250.83 & $17.98 \mathrm{~b}$ & $20.97 a$ \\
\hline Head-Type & $273.65 a$ & $162.00 \mathrm{~b}$ & $258.79 a$ & 104.86 & $27.36 a$ & $16.20 \mathrm{~b}$ \\
\hline
\end{tabular}

FC - First Cropping, SC - Second Cropping

Means in a column having the same letter are not significantly different at $5 \%$ level.

The yield data among varieties indicate an inconsistent trend wherein headtype lettuce obtained higher yield on first cropping while leafy lettuce on the second cropping. One possible reason for lower marketable yield for the head-type during the second cropping was several lettuce heads formed very late with the usual time happened to produce less compact and smaller heads. Another possible factor would be using a different variety for leafy-type in the second cropping though they are in "similar type" they could be genetically different.

\section{Disease Incidence}

Lettuce planted under the protected structure had a lower incidence of soft rot and white (sclerotinia) mould compared with the plants grown in the open field (Table 3). Between the varieties, head-type lettuce had a lower incidence of disease than leafy lettuce during the first cropping period. One of the possible reason for reduced disease incidence inside the structure is the absence of rain entry (Rogers et al 2003) as rain splash is another way whereby inoculum from the soil is introduced that ables to transfer pathogen from one plant to another plant. Second cropping recorded the highest incidence of diseases on lettuce grown at the open field which might be due to having the coolest temperature (from all cropping) that likely created higher humidity along with faster wind speed $(2.56 \mathrm{~km}$ per hour) compared with the first cropping ( $2 \mathrm{~km}$ per hour) possibly created damages on plant parts that became an entry point for pathogens. Thus, protected structures could be use as protection of plants from rain splash and extreme wind.

Table 3. Disease incidence of two lettuce varieties grown under protected and open field cultivation

\begin{tabular}{lll}
\hline \multirow{2}{*}{ Treatments } & \multicolumn{2}{c}{ Disease Incidence } \\
\cline { 2 - 3 } & FC & SC \\
\hline Cultivation System (A) & $1.16 \mathrm{~b}$ & $1.67 \mathrm{~b}$ \\
Protective Cropping & $1.50 \mathrm{a}$ & $3.33 \mathrm{a}$ \\
$\quad$ Open Field & $1.50 \mathrm{a}$ & \\
\hline Variety (B) & $1.16 \mathrm{~b}$ & 2.16 \\
Leafy-Type & 2.33 \\
Head-Type &
\end{tabular}

FC - First Cropping, SC - Second Cropping

Means in a column having the same letter are not significantly different at $5 \%$ level. 
Gonzaga et al

Table 4. Climatological pattern during the conduct of study for two cropping periods

\begin{tabular}{lccc}
\hline \multicolumn{1}{c}{ Months, 2016 } & $\begin{array}{c}\text { Average Daily Temperature } \\
\left({ }^{\circ} \mathrm{C}\right)\end{array}$ & $\begin{array}{r}\text { Average Daily Rainfall } \\
(\mathrm{mm})\end{array}$ & $\begin{array}{c}\text { Average Wind Speed } \\
(\mathrm{km} \text { per hour) }\end{array}$ \\
\hline July & 23.7 & 324.6 & 2.6 \\
August & 24.3 & 238.8 & 2.6 \\
September & 23.7 & 156.7 & 2.0 \\
October & 23.7 & 284.0 & 1.8 \\
\hline \multicolumn{1}{l}{ Months, 2017 } & & & \\
\hline February & 22.2 & 152.4 & 2.6 \\
March & 22.8 & 290.3 & 2.5 \\
April & 23.5 & 204.5 & 2.6 \\
\hline
\end{tabular}

\section{CONCLUSIONS}

The study shown that the protected cropping system increased crown size. yield and produced healthier plants with reduced incidence of diseases. It could be a great asset in the enhancement and sustainability of lettuce production in preventing futher damage on crops due to excessive rainfall and wind but would not be profitable when use during warmer months. Leafy-type lettuce when grown inside the protected shelters produced larger crown size and did reduced incidence of diseases among head-type lettuce compared to plants grown under open field condition.

\section{REFERENCES}

Armenia PT, Menz KM, Rogers GS, Gonzaga ZC, Gerona RG \& Tausa ER. 2013. Economics of vegetable production under protected cropping structures in the Eastern Visayas, Philippines. Smallholder HOPES-horticulture, people and soil (pp112)

Briones RM and Galang IMR. (2012). Assessment of Prospective Impact of Fruits and Vegetables Research at the Industry Level in the Philippines: the Case of the ACIAR-PCAARRD Horticulture Project (No. 2012-40). PIDS Discussion Paper Series

Everaarts AP and De Putter H. 2008, FEBRUARY. Opportunities and constraints for improved vegetable production technology in tropical Asia. In International Symposium on the Socio-Economic Impact of Modern Vegetable Production Technology in Tropical Asia 809 (pp55-68)

Fang-Asan MLD, Dagupen MKT \& Digal LN. (2009). Lettuce Supply Chains and Marketing Margins in Benguet, Philippines. BANWA Archives 6(2):32-42

Gerona RG, Gonzaga ZC, Capuno OB, Armenia PT, Loreto MB, Nuñez LB \& Dimabuyu HB. 2014, AUGUST. Sustainable vegetable production through the use of lowcost protective structures: a farmer's experience in Bontoc, southern Leyte, Philippines. In XXIX International Horticultural Congress on Horticulture: Sustaining Lives, Livelihoods and Landscapes (IHC2014): 1128 (pp171-176)

Gonzaga ZC, Capuno OB, Loreto MB, Gerona RG, Borines LM, Tulin AT \& Rogers GS. 2013. Low-cost protected cultivation: enhancing year-round production of highvalue vegetables in the Philippines. Smallholder HOPES-horticulture, people and soil (pp123) 
Growth and yield performance of lettuce

Jensen MH. 2001. APRIL. Controlled Environment agriculture in deserts, tropics and temperate regions-A World Review. In International Symposium on Design and Environmental Control of Tropical and Subtropical Greenhouses 578 (pp19-25)

Lamont WJ. 2009. Overview of the use of high tunnels worldwide. HortTechnology 19(1):25-29

Mashego DC. 2007. The production of vegetable crops under protection for smallscale farming situations (PhD dissertation)

Rogers G, Capuno OB, Gonzaga ZC, Armenia PT, Menz K \& Badgery-Parker J. 2013. Enhancing profitability of selected vegetable value chains in the southern Philippines and Australia

Waycott W. 2004. US. Patent No. 6,689,941. Washington, DC: US. Patent and Trademark Office

Wittwer SH and Castilla N. 1995. Protected cultivation of horticultural crops worldwide. HortTechnology 5(1):6-23 